\title{
Doing justice to their history: London's BAME students and their teachers reflecting on decolonising the history curriculum
}

\author{
Robert Guyver \\ Independent Academic
}

\begin{abstract}
This paper examines qualitative data emerging from interviews in five London schools with different groups of BAME ([British] Black, Asian and Minority Ethnic) students aged between 14 and 18 (a total of 33), and seven of their teachers. The students are questioned about their reactions to the taught curriculum especially in the light of their sometimes complex but common postcolonial identities. The methodology followed here, that of Bourdieusian relational phenomenology (Atkinson, 2020), mirrors both the literature review and the conclusions, in that the history of the movement of peoples as a consequence of colonisation and empire not only explains the way Britain is but also defines an imperative for societal and curriculum change. The contextual literature relates to some of the history of migration and settlement including in London, and to some aspects of historiography, especially the work of Peter Fryer (1984/2018), Catherine Hall (2002), Rosina Visram $(1994,2002)$ and David Olusoga $(2014,2015)$ to demonstrate that Black history is British history and that there is a mutual responsibility to rediscover what has been hidden and forgotten. But that history, with its power relations, is also intertwined and interrelated with relationships between citizens in society today. The core and periphery paradigm (Mycock, 2017) is clearly reflected in the concept of double-consciousness (Du Bois, 1903; Gilroy, 1993) as both a personal and curriculum dimension. The findings demonstrate the importance of a history education that connects migration, empire and postcoloniality, for all citizens, including those wielding official power. Four themes emerge for analysis: double-consciousness; curriculum and pedagogy; understanding power relations; and citizenship, social justice and curriculum change.
\end{abstract}

\section{KEYWORDS}

Double-consciousness, core and metropole, relational phenomenology, habitus and field, power relations, social justice, curriculum and society, colonisation, empire, decolonisation 


\section{Citation}

Guyver, R. (2021). Doing justice to their history: London's BAME students and their teachers reflecting on decolonising the history curriculum. Historical Encounters, 8(2), 156-174. https://doi.org/10.52289/hej8.209

\section{COPYRIGHT}

(C) Copyright retained by Author/s

Published 6 May 2021 | Metadata Note added 23 July 2021

Distributed under a CC BY-NC-ND 4.0 License

\section{Introduction}

This is a study, conducted through interview-conversations in April and May 2018, with groups of teenage BAME students, mostly female, and their teachers, in five secondary schools across London reflecting on decolonising the history curriculum that they had been taught or were teaching. The study explores how they evaluated personal identities and family histories in relationship to their history education. The interviews were undertaken on the understanding that neither the schools nor the teachers or students would be named, but that the identity-heritages of the interviewees would be revealed. The difficult decisions associated with representing the findings of this investigation have been about how to organise the results and make the necessary abbreviations or compressions of extended and detailed conversations. Rather than presenting this school-by-school it was decided to synthesise the findings through four themes which are discussed under the methodology below.

\section{Literature review}

Whereas the interview-conversations themselves reveal the reading preferences of both teachers and students, the research data has to be put in a wider context of both the UK and particularly English society (bearing in mind the multiple jurisdictions of the UK) at this time (April/May 2018), and where the History curriculum stood, with its related dynamics. Similarly, the discussions in the schools reveal how BAME dimensions had enhanced the taught curriculum with examples of British rather than American campaigners for justice (e.g. Paul Stephenson, Claudia Jones and Asquith Xavier), and some focus on victims of injustice (e.g. Kelso Cochrane and Stephen Lawrence $^{1}$ ). Migration, with related citizenship and inclusion implications, had become a core issue both in society itself and in the curriculum. The EU Referendum campaign (Feb-June 2016) was strongly associated with a debate about taking back control at different levels, including of who enters the country. The debate about how earlier migrants had been treated came to the fore at this time (April 2018) with revelations of individual cases in the Windrush ${ }^{2}$ scandal. $^{2}$

The last national curriculum changes had taken place five years earlier in the summer of 2013, after some robust debate in response to the government's much-criticised draft history curriculum (February, 2013), which was set out as a celebratory canon of mainly English historical events, many of them military. This was modified after interventions within governmentconvened meetings from individuals associated with interest groups, significant among them the Historical Association, the Royal Historical Society and the Schools History Project. The motivation within these redrafting sessions was not so much about how the curriculum might be decolonised, but about how it might be reframed to offer a sensible relationship between the proposed substantive content and an inquiry approach. The national curriculum itself as a cohering educational force in society had been undermined by two factors. First, in some if not many schools the old-style three-year Key Stage 3 History course, covering 11 to 14 year olds, had been reduced by senior managers to two years with Year 9 being used to extend the lead-in to 
GCSE examinations, especially to support subjects which were considered to be more important than History. The other factor was a structural change whereby old local authority schools were becoming centrally-funded academies, often within multi-academy trusts (MATs) none of which by law had to study the national curriculum. History courses in each MAT might be different. This situation has recently been examined by Mary Woolley (2020), following earlier concerns by Stephen Ball (2015). There would be no guarantee of students leaving school at aged 16 or 18 having an understanding of migration or empire unless their teachers were committed to achieving it.

In April 2018 when the interviews were started there were revelations in The Guardian about the treatment of vulnerable individuals from within the Windrush Generation, with mainly West Indian/Caribbean heritages. There were deportations or threats of deportation as part of the UK Home Office's aggressive 'hostile environment' policy. The associated rights to work and remain in the country were being denied to those who could not find the correct paperwork. Details were being published on a daily basis at the time of the April 2018 Commonwealth Heads of Government Meeting (CHOGM), ${ }^{3}$ which was being held in London. These reports were later published in book-form by Amelia Gentleman (2019). Her pursuit of individual cases was notable, particularly the impact that government policy had on the lives and families of Sarah O'Connor, Anthony Bryan and Paulette Wilson. For these unfortunate victims, the political was personal, feeding into their double-consciousness in a real way.

The original Windrush arrivals (22 June 1948) had been interviewed by Peter Fryer whose Staying Power (1984/2018) would become a seminal work. Awareness of a sense of mutually experienced effort during wartime and of new opportunities for work in a devastated post-war Britain catalysed this particular migration, and individual experiences would be further illustrated by Stephen Bourne in Motherland Calls (2012), and by David Olusoga in The World's War - Forgotten Soldiers of Empire (2014). The Windrush Generation suffered from discrimination and racial abuse on the streets of London when they first arrived, and subsequently. The related locales, broadly speaking of 'metropole' (in this case London) and 'colony' (in the case of Windrush and in 1948, the various large and small island jurisdictions in the Caribbean, that were then colonies of the UK, or had similar status) have been discussed by Catherine Hall (2002) drawing on the work of Cooper and Stoler (1997), making a strong recommendation that the two histories (of the metropole-based power and the once colonised world) should be seen in the same analytic frame, stressing that the one could not be understood without the other. The missing element in this narrative was the wider history of the British Empire, and the fact that the West Indies had been where slavery had operated. In addition, there was the link to Africa as those same enslaved people were transported across the Atlantic from West Africa, some being brought in from places closer to the centre of the continent.

As Visram has stressed, "What is important is the relationship between these several histories. Black history is part of British history. As such it is central to school history" (1994, p. 60). Hall's work reaffirmed this view that Britain cannot be "understood in itself without reference to other histories" (2002, p. 9). She went on to assert that the nation can be understood "only by defining what is not part of it, for identity depends on the outside, on the marking both of its positive presence and content and of its negative and excluded parts" (p. 9). Mycock reflected that there is "a correlation between the extent of migration from the colonial periphery to the post-colonial metropole and the intensity of the 'politics of empire' and history education" (2017, p. 402).

Imperatives to transform societal and school experiences would come from different directions and at different times. Reni Eddo-Lodge (2016) would put into words her unhappiness about "how we understand ourselves through the eyes of someone else" (p. 78) and her sense of "a kind of displacement that went hand-in-hand with Britain's collective forgetting of black contributions to British history" (p. 79). Her complaint was that they were always American examples of the struggle for human rights that she had to study at school, when there were in fact British examples much closer to home, like the campaigning of Paul Stephenson in the Bristol Bus Boycott of 1963. Eddo-Lodge tells the reader that her family would never let her forget her Nigerian roots, but she describes herself as British-Nigerian. In a famous passage W.E.B. Du Bois 
echoes almost exactly what she describes. This 'double-consciousness' was a "sense of always looking at one's self through the eyes of others, of measuring one's soul by the tape of a world that looks on in amused contempt and pity." Being both Black and American he identified as one who "ever feels his twoness ... two souls, two thoughts, two unreconciled strivings; two warring ideals in one dark body, whose dogged strength alone keeps it from being torn asunder" (Du Bois, 1903, pp. 3-4).

The notion of double-consciousness would be developed by Paul Gilroy who claimed that "it acquires an ethno-psychiatric flavour specific to colonial and semi-colonial social life" (1993, p. 161), and implied that he prefers the term 'double vision.' Nevertheless, what becomes clear is that the double-consciousness or double vision is required on both sides of the debate, Black and white.

Television would play its part in normalising awareness of double-consciousness in people's identities, especially in the Who Do You Think You Are series, which drew on the multiple locations of the family histories of celebrities like Alistair McGowan [Scotland, India], 2007; Hugh Quarshie [Ghana, Netherlands], 2011; Nitin Ganatra [Gujurat, Kenya], 2013; Adil Ray [Pakistan, Kenya, Uganda], 2020; Anita Rani [India], 2018); Reggie Yates [Ghana], 2019; Naomi Harris [Jamaica, Trinidad \& Tobago, Grenada], 2019; and Sunetra Sarker [India, Bangladesh], 2019. David Olusoga's A House through Time (BBC, 2018-2020), three sets of programmes, located in Liverpool, Newcastle and Bristol, achieved in many of its case-studies the objective of seeing the metropolecolony dynamic in a single analytic frame. He would through his other television work bring home two significant developments. The first, The Unwanted - The Secret Windrush Files (BBC, 2019) was a poignant follow-up to the 2018 Windrush revelations in which individual stories were told of how the official 'hostile environment' and the unequal, unjust power relations associated with it, felt and looked in the unofficial lives of individuals. The second, Britain's Forgotten Slave-Owners (BBC, 2020) provided the background to the work of the UCL research-team, led by Catherine Hall, on Legacies of British Slave-Ownership (Hall et al., 2014), demonstrating that the industrial revolution and the growth of railways would not have been possible without the re-investment following vast compensation payments made to individuals who had lost income from slave ownership.

Linking these elements back to society itself, that is to both 'the public' and a significant institution, the Home Office (which is also responsible for the police force), and to a linked awareness of the importance of curriculum change across society, is this extract from Wendy Williams's Windrush Lessons Learned Review (March, 2020):

\begin{abstract}
The Windrush scandal was in part able to happen because of the public's and officials' poor understanding of Britain's colonial history, the history of inward and outward migration, and the history of black Britons. A lack of institutional memory or comprehensive understanding of the impact of the complex immigration situation created by successive legislative changes, set against an unwillingness or inability to learn from past mistakes, or to engage with experts and local communities, has compounded this situation. Officials need to understand the past to inform the present and the future of immigration policy. (p. 139)
\end{abstract}

Her 'Recommendation 6' was for Home Office staff re-education along exactly the same lines as identified above, and for annual reporting of the same. Of similar concern was the high number of stop-and-search incidents between police and the BAME population, despite denials that there was institutional racism in the force. It is ironic that the Home Office's own publication offering guidance for those aspiring to British citizenship should itself be less than inclusive (or diverse). It includes a chapter of officially approved history on which immigrants would have to submit themselves for testing. However, on 21 July 2020, 181 historians in an open letter published by the Historical Association (HA, 2020) subjected the history section of Life in the UK (LIUK) (2013) to excoriating criticism. The signatories argued that this complacent narrative of British power and exceptionalism, which failed to give any credit for indigenous agency in independence 
struggles, and downplayed both the impact of colonialism and the richly diverse legacy of postcolonial migration, was in urgent need of amendment.

These concerns also emerged as central to the TIDE-Runnymede Report on Teaching Migration, Belonging and Empire in Secondary Schools. Its authors (McIntosh, Todd \& Das, 2019) noted that "migration and empire are not marginal events: they are central to our national story. As it stands, the story we are telling is incomplete" (p. 4). They also make the important observation that "to adequately prepare students to be tolerant, confident citizens, these topics must be understood as integral both to our history and to the richness of British culture" (p. 4). So, not only is the image of Britain presented to migrants an inadequate one, similarly the image being taught to the 'settled' population is also a distorted one, in urgent need of change, and for the same reason that the LIUK booklet is widely considered now to be unsuitable. A shared vision for citizenship has to have a deeper, broader historical dimension with a sense of mutual responsibility.

The momentum for change has gathered pace in the wake of the Black Lives Matter movement and since the death in custody in the USA of George Floyd on 25 May 2020. The toppling less than a fortnight later in Bristol on 7 June, 2020 of the listed statue of Edward Colston (1636-1731), beneficiary of the slave trade through the Royal African Company and later local philanthropist, indicated that feelings about celebrating the life of a such a man were running high. An extended debate in the House of Commons on 20 October 2020 coincided with Black History Month, and revealed a widespread and perceptive interest in these matters, including from MPs with postcolonial heritages (Hansard, 2020).

What follows is a section on the thinking behind the methodology of this research project, but at a deeper level the relational phenomenology which underpins it is itself a feature of the corresponding power-play at work in society.

\section{Methodology}

The collecting of data with groups of 14, Y9 students, aged 13 and 14, 12, Y11 students, aged 15 and16, three, Y12 students, aged 16 and 17, and four, Y13 students, aged 17 and 18, amounting to 33 (30 female, three male) and their teachers (a total of seven) was conducted through interviews which developed naturally into conversations. This took place on five different days (April 30; 3, 11, 16, and 22 May, 2018) in five different locations (South London, East London, West London, and North London). Tables 1-5 include details of the teachers and of the heritages and year groups of the students. An explanation of the significance of the school year can be seen in Table 6 . The different sets of questions are given in Table 7. Having taught in London himself, for many years as a Head of History, Martin Spafford ${ }^{4}$ (the interviewer) asked his colleagues in the London history teaching community if they could request in their own schools volunteer BAME students who would be willing to meet in relatively small groups to discuss curriculum and identity matters from their own perspectives.

The presentation of all the data as later transcribed by the interviewer (which stands at over 75,000 words) would not have been possible in a single article. The problem has been to decide on how best to analyse this data. The solution has been found in a combination of (a) Bourdieusian theory as developed recently by Atkinson (2020), especially that of relational phenomenology, and (b) the adoption of a thematic approach arising from a reconfiguration of the questions and responses into corresponding sets of 'habituses' and 'fields', with an emphasis in this case on habitus being associated with personal dispositions and fields as the areas in which these dispositions work (See Tables 8 and 9). The dynamic for analysis, which has conveniently allowed for the emergence of four themes, has arisen from identifying sets of habitus-field reactions. Nevertheless, it has proved impossible to equate themes exactly with corresponding fields and habituses, as Habitus 1 relates to both to personal and to curriculum fields (Themes 1 and 2), and Field 3 relates to Themes 3 and 4. 
The interviews can be seen as conversations and thus as forms of discourse about personal and school experiences of how decolonising the curriculum is linked to inclusion and diversity. These embrace citizenship concepts as well as curricular elements. The methodology also draws on Finlay's interpretation of the two 'iterative stages' of phenomenological research, and thus the conversations within these interviews can be seen as linking the students' and teachers' lives in the metropole (in this case London) (a) holistically to past and present lives in the wider world and (b) dialectically (Finlay, 2012, p. 174), where '[s] hared ways of being were learnt in microexchanges of learning within groups' (Sales, 2012, p. 75).

Table 8 shows how the relationship between Habitus and Field works with a corresponding element of relational phenomenology and relates to the themes (see Table 9).

\section{Findings}

\section{Theme 1: Double-consciousness}

This theme can operate at several different levels, drawing on different objects of consciousness, including the geographical and historical dimensions of family life (the students' life-world experiences), and within that the habitus-field inter-play as reflected in awareness of past and present family involvement in the relationship between the 'periphery' (broadly, the former 'colony') and the 'core' as the locus of former colonising power and present place of residence (the 'metropole'). In this section double-consciousness as an element emerging in the interviewconversations will be examined in the context of reflections about aspects of family life, and then in the next section in reflections about how these life-world experiences impact on the students' views about the history curriculum and how it might be amended.

Visits mentioned in the conversations included family holiday visits to the Middle East [Somalia], Africa [Ghana], and the Far East [Vietnam]). Ghana was also the destination of one of the teachers (T7) for research into her university dissertation on family history. Her knowledge of Ghanaian culture would feed back into her teaching when she taught her class a Ghanaian song which caught the spirit of independence. Two of Ghana's maritime castles linked to the slave trade featured (St George's d'Elmina and Cape Coast Castle). The Nkrumah Memorial Park in Accra was visited (by student G-F11C) and fed back into a better contextual understanding. "Ghana was under English rule until Kwame Nkrumah who freed us from the British Empire."

The overseas trips were linked to discussions about the extent to which the students felt they could still identify as belonging to their countries of origin or felt themselves to be totally British. Family generosity was appreciated but so was the chance to get back to London. A male student in School E who identified as mixed Vietnamese (mother) and Cumbrian (father) regretted not having had school input on the Vietnam War before visiting Da Nang and the massacre site at My Lai. The father's belief that he was descended from Vikings added to the richness and brought a migratory element to the British identity. Many of the students and at least one of the teachers (the teacher with an Irish heritage in School C) identified as Londoners.

Some of the family histories suggested a more traumatic past. In School D a Y9 student linked to both São Tomé and Principé and Portugal had a grandmother who it seemed knew about or might even have witnessed a massacre in 1953. Although slavery there officially ended in 1875, labour conditions were little better than slavery and the 1953 revolt by oppressed contract labourers (the grandmother was probably one of these) was violently put down and the bodies thrown into the sea. This was commemorated annually on the beach, but the memory of this colonial conflict, which had fed into demands for independence, was passed on within this family.

In more than one case students had parentage mirrored the multi-angular nature of the slave trade, with one parent from the Caribbean and another from mainland Africa: 
School A students

Y9 - Nigeria/St Vincent

Y9 - Dominica/Nigeria/Ireland

Y12 - Sierra Leone/Liberia/Guinea/Jamaica

Y13 - St Lucia/Zambia

The Y9 student (above) with links to St Vincent could be even more specific about the location, which was an island named Bequia to the south of St Vincent, where there had been a Scottish presence. Indeed, her mother, undoubtedly descended from slaves, had had a Scottish maiden name. The Legacies of Slavery UCL website indicates that in 1817 there were 482 enslaved Africans on Bequia.

Within family memory there were accounts of experiences in the metropole itself. One student (D-F9A [Dominica/Nigeria/Ireland]) told about how there had been a proactive and deliberate move to gather the paperwork together to apply for and gain citizenship soon after arrival, because the family had sensed that one day there might be an attempt to 'send them back.' Recent events linked to the 'hostile environment' had proved that this had indeed been a necessary precaution. This family with members working "in banks and stuff" had saved enough money to be able to do this. There was a strong sense of having distanced themselves from the Caribbean as they had lost the patois and had slowly been assimilated into London society. The recently revealed cases evoked some sympathy in the students. These Windrush scandal victims "didn't have the foresight."

Student A-F9E (India/Jamaica/Dominica/France) couldn't understand until she was older what her grandmother meant by "all that I have done for you." In fact, it meant living in what was then a racist anti-immigrant society characterised by prejudicial exclusionary signs put up by landlords or landladies. It was the Bristol bus boycott which led to some legal changes in race relations, both in employment and in housing.

Another student B-F9A (with heritages linked to the Philippines and China) who was raised in the Philippines was expected by her mother to change in the way she related to people because she was in London or Britain. But although it seems she could relate positively and seek to treat people equally she nevertheless complained of there being a 'silent prejudicity' in society where she felt a negative sense of being different.

The Y13 School A student (A-F13A) with links to both St Lucia and Zambia was among the most articulate and sophisticated in her responses. She had a strong locational sense enhanced by two strands of family influence: her uncle and her grandfather, whose views in some ways complicated a polarised postcolonial narrative. She linked Cecil Rhodes with De Beer diamonds who were still employing people in Zambia and other parts of Africa.

Yes, because I think it's the De Beer diamonds and I was like, I was looking up diamonds and I was, like, De Beer's nice, and then I think it was my uncle who said, oh yes, Cecil Rhodes was, like, a founder of De Beer. And then I started looking into that and, yes, that's an interesting part of history. And yes, that's quite interesting, and then learning about the freedom fighters in Zambia, so like when it arose. So, like, my grandad, he was like, he was head of education at the Commonwealth, so his friends, they were like the freedom fighters, so that was interesting.

She was not in favour of mixing up all cultures into one mixing pot, because she saw cultures and cultural practices, like sharia law as having context-specific rather than universal validity. She was against a cosmopolitan multiculturalism, but in favour of a 'symbiosis,' a living together, a toleration of cultures, but not a hegemonic relationship. Thus, she claimed that:

a culture is a culture for a reason...But if from the side of pluralist multiculturalism, I think it goes on to what you were saying about having that diversity within unity which is everyone's allowed to celebrate their culture and 
represent it and, you know, almost have it within society and have that, like, that symbiosis rather than, like, mashing it together.

She used the word 'represented' more than once, and applied it to the link between being in society and the history that was studied in school, although she like one or two others, including at least one of the teachers (T1, of Nigerian heritage) speaking about an earlier experience, had found that they and their culture were represented more in English (literature) lessons than in History.

\title{
Theme 2: Curriculum and pedagogy
}

This section examines how the existing frameworks (including both the curriculum itself and the way it is taught) within which the colonisation, imperial and decolonisation elements appear in the history curriculum are experienced by these students and enacted by their teachers.

\begin{abstract}
There seemed to be a strong relationship between respect to individuals shown in history lessons and the students feeling that they themselves were valued. This was the case in School A with the Y9 students discussing the film Pocahontas where there was resistance to the native Americans being described as 'savages,' and a plea for more depth and more biographical detail rather than generalisation. This was echoed in School B with an extended conversation involving students with heritages linked to Algeria (C-F11B), Pakistan (B-F11B) and Somalia (A-F11B). Student B-F11B (Pakistan) said: "I always imagine, I don't want to be offensive or anything, I just imagine a white guy with a beard hopping off a ship and saying, like, hi this is mine", that he had walked up a beach (they were thinking of Roanoke in 1584) and just claimed the land for himself. This prompted two comments from the student with an Algerian heritage (C-F11B): "It's not what country it was but the treatment of that country"; and "It's not about seeing colour ... it's how you treat colour."
\end{abstract}

There were mixed views about the value of Tudor history, with one student claiming to have really enjoyed the Y10 Elizabethan unit (which had included the first attempts at colonisation). Others had not liked the repetition either in primary school itself (although the national curriculum had originally been designed to avoid repetition) or the fact that 'Tudors' was studied at both Key Stage 2 and Key Stage 3. Henry VIII's attitude to his wives came in for much criticism in School D, as they did not approve of his killing of women. Although the interviewer in conversation tried to argue that this was a period of great change, the students with heritages linked to Algeria (C-F9D), Somalia/Yemen/Saudi Arabia (B-F9D), Montserrat/USA (F-F9D), and São Tomé \& Principé/Portugal (A-F9D) disapproved of any hero-worship of this king as, in the words of Student A-F9D he "never changed the world," rather contradicting the interviewer, although these students were thinking of stopping racism and genocide. Another view of the traditional "kings and queens' approach was that it seemed that Tudors or Tudors-and-Stuarts were followed by a complacently proud narrative of how powerful Britain became through imperial expansion with no thought for the impact.

Teachers 4 and 5 (School C) did not teach kings and queens and adopted a history from below approach, encouraging their students to become more reflective and critical, modelling their teaching units and lessons on the structure of a dissertation, inquiry-based, chapter by chapter, also encouraging the use of extracts from historians. Teacher 7 (School E) of Ghanaian heritage, allowed one her students with links to Ireland, to teach a lesson about the Irish Troubles.

\section{Theme 3: Understanding power relations}

Power relations are seen in these conversations to operate at several levels. The power of the government to decide on a universal policy that all schools would have to follow was regarded as having positive value if the curriculum requirements were for all schools and inclusive (according 
to the School D teacher [T5], a Lead Practitioner [History] of Jewish heritage). But this was being frustrated by others wielding different powers, such as school senior managers deciding on reducing the time for the Key Stage 3 programme, or exam boards promoting syllabuses that fell short of the need to include links between empire and migration. The interviewer (Martin Spafford), the teachers and the students all commented on power relations between socioeconomic groups as a factor in history. Enslavement in the $18^{\text {th }}$ and $19^{\text {th }}$ centuries could be seen in factory conditions in the UK, and in the harsh treatment of white sailors on slave ships.

The concept of 'the personal is political' works at several different levels, but it was used specifically by Teacher D (as above) to refer to his approval of 'stories from below', not naming Raphael Samuel but referring to his school of thought (feminist and Marxist) (see Samuel, 1994). His method was to explore big themes though an SHP-style inquiry-led approach related to individuals like Equiano, Claudia Jones who initiated the Notting Hill Carnival to commemorate the tragically cut-short life of Kelso Cochrane, and the story of Kelso himself. His own research, linked to work as an OCR examiner, had led him to read letters from the East India Company, about slave ships being attacked in in the 1670 s. He said, "It's the story, the narrative which is more engaging to me and always has been. That's what I like to share."

Both teachers and students saw a need to see history from below from a 'colonised' point of view. The colonised (mainly in Africa, the Caribbean, and South Asia) were clearly identified by the students as individuals with their own stories (not marginalised) who were in a power relationship with the coloniser. Colonisers, and indeed the corresponding histories about them, were regarded as showing signs of complacency and insensitivity about the power being exercised, mainly because the accounts did not sufficiently place the colonised into the reality of the powernarrative. There was a plea by the students and their teachers for the restoration of these forgotten or marginalised stories, a plea also seen in the work of Fryer (2010), Bourne (2012) and Olusoga $(2014,2015,2016)$.

Studying both the pre- and postcolonial histories of formerly colonised jurisdictions after they became independent nations, albeit in many cases having a continuing relationship with the former colonising power (and each other) through the Commonwealth, was seen as an area that had been neglected. Blame was placed by teachers on the government for changing the $2007 / 2008$ curriculum which had required this element (i.e. precolonial civilisations), but now it was merely allowed. This deficit was believed to diminish the status of the citizens of the relatively 'new' postcolonial countries, because a great deal had happened in those locations (with which the students had ongoing family links) before and after colonisation, and ignorance of these histories tended to feed back into street-prejudice about migrant-settlers from these places.

\section{Theme 4: Citizenship, social justice and curriculum change}

It is clear that all of the teachers believed that history education was strongly linked to a range of citizenship dimensions, including the enablement of agency or advocacy. A much-used text across the schools was Mohamud and Whitburn (2016) on Doing justice to history: Transforming Black history in secondary schools, although the teachers did not generally see 'Black history' as separate from history as a whole. These authors themselves recognised the salience of Bourdieu's theory of habitus to explain in biographical examples different forms of response (and thus of agency) to injustice.

School A's teacher (T1) encouraged his students to use their right to vote and to be aware of how society can scapegoat others, as happened in Germany in the 1930s. Both teachers in School B (T2, T3) in East London were deeply aware of the importance of discussing current affairs and setting them in an historical frame. They knew that there were different views about migration among the students (and their families), but like T1, wanted to explore in a rigorous way how such prejudices can lead to discrimination. T4 and T5 (with heritages linked to Ireland and East Africa) used their unit on the Matchwomen, Irish migrants from families affected by the Famine, to show how these women had campaigned against injustices over pay, and had been empowered to travel 
the world to tell their stories. Other stories told in School $\mathrm{C}$ about injustice did not have such successful outcomes, such as the Morant Bay rebellion in Jamaica in 1865, which led to the hanging of activist Paul Bogle. Similarly, the narrative about the West India Regiment did not end as expected. The example of Paul Stephenson and the Bristol Bus Boycott was also widely used, significantly because this campaign in 1963 led to changes in employment and housing legislation.

A lack of understanding between communities was seen to have a curriculum basis. The teacher in School D said:

\begin{abstract}
It absolutely is important [in a school without diverse intake, also]. I remember some reports came out in the mid-90s or so about teaching in monocultural communities and some of the biggest challenges in those communities - or in communities that are not particularly well integrated, in Oldham and places like that - part of the reasons why we don't have strong community cohesion in those places is because there is a lack of understanding of where we've come from and how these histories are intertwined and interrelated. For too long the history narrative has been narrow, Eurocentric, male dominated - but we know the arguments about that. That phrase 'being hidden from history' has happened for too long so it needs to be challenged.
\end{abstract}

In his poem, 'The British - serves 60 million', Benjamin Zephaniah (2000) writes:

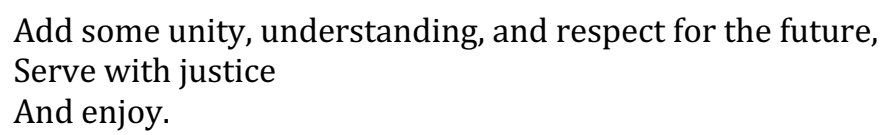

Note: All the ingredients are equally important. Treating one ingredient better than another will leave a bitter unpleasant taste.

Warning: An unequal spread of justice will damage the people and cause pain. Give justice and equality to all. (p. 39)

\title{
Synthesis and discussion
}

This section will briefly examine how the themes relate to each other, in the spirit of relational phenomenology. Double-consciousness is a personal factor which can and does feed into a curriculum dynamic. It had been enthusiastically appropriated by the teachers, even those who did not have BAME backgrounds; and is something that the students brought to their understanding of curriculum, empathising with those adversely affected by unfair power relations. The ability to identify with those at the receiving end of empire, colonisation and even decolonisation, gives them an enhanced sense of perspective and significance. There are strong signs that the teachers were making every effort to construct syllabuses that are relevant to the demographic of their students. The students appreciated this and applied their doubleconsciousness to some of the more mundane British history topics, re-interpreting them, using what one School C student (with heritage links to Ireland/Grenada) called retro-think. Another student (with links to Ghana, also in School C) could define her experience of doubleconsciousness as being linked to both the London/British culture and the Ghanaian one. The same student was able to articulate the sense of a need more strongly to connect these elements with her friends in the classroom. The British-Ghanaian teacher in School E was however able to provide the connection by teaching her class a Ga language song which reflected the spirit of independence, and which the class were singing for days afterwards. 


\section{Conclusions and recommendations}

In many ways the conversations reported on in this study are about the relationship between (a) a process of assimilating a history curriculum at different age-stages, either pre-exam (Key Stage 3), or exam (i.e. GCSE or A-Level) and (b) aspects of society itself. This process has involved a double or multiple consciousness of significant factors that have come together. The students, their families and their teachers, most of whom are already British citizens or soon will be, are members of a society which they are seeking to influence and change. The critical-dialogic calibrating process brought to the different sets of learning situations seen in these interviewconversations mirrors an expectation of change both in the curriculum and in society. The lifeworld experiences seen in this study show that these two elements need to breathe out to accommodate new narratives and perspectives, and to recognise injustices, recent and in the more distant past. The thinking behind the history section of the Home Office's Life in the UK booklet demonstrates a rather old-fashioned view that the host-society has a fixed history which has to be learnt, whereas what emerges from the exchanges in these five schools is that the positive and deliberate accommodation of new narratives 'from below' organically enriches, contests and unsettles the old canon. The treatment of minorities in society, a long story, reveals a power dynamic experienced personally by many of the interviewees and their families. This is a multifaceted story of society and curriculum facing each other, sometimes uncomfortably - a story that needs to be re-examined and re-defined in schools, for all students who attend them.

The fundamental challenge is for the nation-state itself to process, accommodate, assimilate and reframe the narratives of all its citizens, of whatever ethnicity or colour, and to enable mutual understanding of all people's histories at a national level to reduce prejudice. Both the flaw and in a way the strength in Simon Schama's arguments (2010) at the beginning and end (2013) of the last round of official curriculum debate lay in his stating separately first that migrant-settler groups needed to understand their own histories (he mentioned those from South Asia living in British cities), and second that "history is about other people" (2013, n.p), but these two elements need to be stitched together. A national history curriculum has to enable and support this conjunction. In this respect a national curriculum is not about national history, it is about finding a suitable curriculum for the whole nation. As Teacher D said, these histories which link the core and the periphery, or the colony and metropole are "intertwined and interrelated." And, as the School A eighteen-year old student linked to both St Lucia and Zambia said, what is needed is a unity in diversity, a symbiosis. So, what is becoming an imperative is finding the means whereby these 'intertwinings' can be explored, and this is just as crucial for mono-cultural (i.e. 'white' British) communities as for those with high immigrant-settler numbers. Thus, the recommendations of Wendy Williams (2020) coincide with the priorities of the participants in this study.

\section{References}

Atkinson, W. (2020). Bourdieu and after: A guide to relational phenomenology. London: Routledge.

Ball, S. J. (2015). Education, governance and tyranny of numbers. Journal of Education Policy, 30(3), 299-301. https://doi.org/10.1080/02680939.2015.1013271

Bourne, S. (2012). The Motherland calls: Britain's Black servicemen \& women, 1939-45. London: The History Press.

British Broadcasting Company (BBC). (2004-2019). Who do you think you are? (Episode guide, episodes 1-16). Retrieved from

https://www.bbc.co.uk/programmes/b007t575/episodes/guide 
British Broadcasting Company (BBC). (2019). The Unwanted: The Secret Windrush Files (first shown 24 June, 2019).

British Broadcasting Company (BBC) (2018-2020). House through time (Episode guide, episodes 1-3). Retrieved from https://www.bbc.co.uk/programmes/b09164y9/episodes/guide

Centre for the Study of the Legacies of British Slave-ownership [The] (University College London (UCL) with the Hutchins Centre at Harvard). (n.d.). Legacies of British slave ownership. Retrieved from https://www.ucl.ac.uk/lbs/

Cooper, F., \& Stoler, A. L. (1997). Between metropole and colony: Rethinking a research agenda. In F. Cooper \& A.L. Stoler (Eds.), Tensions of empire: Colonial cultures in a bourgeois world. Berkeley: University of California Press.

Du Bois, W. E. B. (2019). The souls of black folk. New York: Clydesdale Press. (First published in 1903, by A. C. McClurg \& Co., Chicago.)

Eddo-Lodge, R. (2016). Forming Blackness through a screen. In N. Shukla (Ed.), The good immigrant (pp. 77-83). London: Unbound.

Finlay, L. (2012). Unfolding the phenomenological research process: Iterative stages of 'seeing afresh'. Journal of Humanistic Psychology, 53(2), 172-201.

https://doi.org/10.1177/0022167812453877

Fryer, P. (1984/2010). Staying power: The history of Black people in Britain. London: Pluto Press.

Gentleman, A. (2019). The Windrush Betrayal: Exposing the Hostile Environment. London: Guardian Faber Publishing.

Gilroy, P. (1993). The Black Atlantic: Modernity and double consciousness. London: Verso.

Gilroy, P. (2002). There ain't no black in the Union Jack. London \& New York: Routledge. (First published in 1987, by Unwin Hyman, Ltd.)

Hall, C. (2002). Civilising subjects: Metropole and colony in the English imagination 1830-1867. Cambridge: Polity.

Hall, C, Draper, N., McClelland, K., Donnington, K., \& Lang, R. (2016). Legacies of British SlaveOwnership. Cambridge: Cambridge University Press. (See also under Centre for the Study of the Legacies of British Slave-ownership [The], above, for details of linked website.)

Hansard (2020, 20 $0^{\text {th }}$ October) House of Commons (UK) debate on Black History Month. Retrieved from https://hansard.parliament.uk/Commons/2020-10-20/debates/5B0E393E8778-4973-B318-C17797DFBB22/BlackHistoryMonth

Historical Association (2020). Historians call for a review of Home Office Citizenship and Settlement Test. Retrieved from https://historyjournal.org.uk/2020/07/21/historians-callfor-a-review-of-home-office-citizenship-and-settlement-test/

Home Office (2013). Life in the United Kingdom: A guide for new residents, $3^{\text {rd }}$ edition. Norwich: The Stationery Office (TSO) on behalf of the Home Office.

McIntosh, K., Todd, J., \& Das, N. (2019). Teaching migration, belonging and empire in secondary schools (TIDE-Runnymede report) (Travel, Transculturality, and Identity in England, c. 15501700 (TIDE). UK: The University of Oxford, The University of Liverpool and the European Research Council). 
Mohamud, A., \& Whitburn, R. (2016). Doing justice to history: Transforming Black history in secondary schools. London: University College London (UCL) Institute of Education Press.

Mycock, A. (2017). After empire: The politics of history education in a post-colonial world. In M. Carretero, S. Berger, \& M. Grever, (Eds.), Palgrave Handbook of Research in Historical Culture and Education (pp.391-410). London: Palgrave Macmillan.

Olusoga, D. (2014). The world's war: Forgotten soldiers of empire. London: Head of Zeus.

Olusoga, D. (2015). Britain's forgotten slave-owners. Two-part BBC2 Documentary (first shown in July).

Olusoga, D. (2016). Black and British: A forgotten history. London: Macmillan.

Runnymede Trust, University of Manchester, University of Cambridge, and The Arts and Humanities Research Council (2016). Our Migration Story (OMS). Retrieved from https://www.ourmigrationstory.org.uk/

Sales, A. (2012). Reconsidering processes of reproduction through learning. (Doctoral dissertation, University of Sheffield, UK).

Samuel, R. (1994). Theatres of memory (Volume I: Past and present in contemporary culture). London: Verso.

Schama, S. (2010, 9th November). Simon Schama: My vision for history in schools. Guardian. Retrieved from https://www.theguardian.com/education/2010/nov/09/future-historyschools

Schama, S. (2013). Simon Schama and Teachers: Our Children, Our History. Hay Festival Event, 30 May. Retrieved from https://www.hayfestival.com/p-6108-simon-schama-and-teachers.aspx

Travel, Transculturality, and Identity in England, c. 1550-1700 (TIDE). University of Oxford, University of Liverpool and the European Research Council. Retrieved from http://www.tideproject.uk

Visram, R. (1994). British history: whose history? Black perspectives on British history. In H. Bourdillon (Ed.), Teaching history (pp. 53-61). London \& New York in association with the Open University: Routledge.

Visram, R. (2002). Asians in Britain: 400 years of history. London: Pluto Press.

Wa Thiong'o, N. (1986). Decolonising the mind: The politics of language in African literature. London: James Currey.

Williams, W. (2020). Windrush lessons learned review: An independent review by Wendy Williams. London: The House of Commons.

Woolley, M. (2020). Teaching history in a neoliberal age: Policy, agency and teacher voice. London \& New York: Routledge.

Zephaniah, B. (2000). The British (serves 60 million). In B. Zephaniah, Wicked world (Puffin Poetry) (pp. 38-39). London: Puffin. 


\section{Appendices}

Table 1: School A students in Y9, Y12 and Y13 and their teacher

\begin{tabular}{|c|c|c|}
\hline \multicolumn{3}{|c|}{$\begin{array}{l}\text { School A } \\
\text { State-maintained Catholic Girls' School (all students female) South London } \\
30 \text { April } 2018 \\
\text { Interviewer: Martin Spafford }\end{array}$} \\
\hline Year group & Student or teacher identifier & Heritage or heritages of student or teacher \\
\hline Y9 & A-F9A & Nigeria/St Vincent \\
\hline Y9 & B-F9A & Philippines/China \\
\hline Y9 & C-F9A & India/Kenya \\
\hline Y9 & D-F9A & Dominica/Nigeria/ Ireland \\
\hline Y12 & A-F12A & Sierra Leone/ Liberia/ Guinea/ Jamaica ... \\
\hline Y12 & B-F12A & Ghana \\
\hline Y12 & C-F12A & Uganda \\
\hline Y13 & A-F13A & St Lucia/Zambia \\
\hline Y13 & B-F13A & Sri Lanka/Portugal \\
\hline Y13 & C-F13A & Cyprus \\
\hline Y13 & D-F13A & Ghana \\
\hline T1 & A-MT1 & $\begin{array}{l}\text { male teacher, Black British, West African heritage } \\
\text { [Nigerian] } \\
\text { (present at all interviews above) }\end{array}$ \\
\hline
\end{tabular}

Table 2: School B Y11 students and their teachers

\begin{tabular}{|c|c|c|}
\hline \multicolumn{3}{|c|}{$\begin{array}{l}\text { School B } \\
\text { State-maintained Mixed Comprehensive School in East London (all students female) } \\
3 \text { May } 2018 \\
\text { Interviewer: Martin Spafford }\end{array}$} \\
\hline Year group & Student or teacher identifier & Heritage or heritages of student or teacher \\
\hline Y11 & A-F11B & Somalia \\
\hline Y11 & B-F11B & Pakistan \\
\hline Y11 & C-F11B & Algeria \\
\hline $\mathrm{T} 2$ & B-FT1 & $\begin{array}{l}\text { Female w/White British heritage Head of History } \\
\text { Present at interview with students }\end{array}$ \\
\hline T3 & B-FT2 & $\begin{array}{l}\text { Female w/White British heritage history teacher } \\
\text { Present at interview with students }\end{array}$ \\
\hline
\end{tabular}

Table 3: School C Y11 students and their teachers

\begin{tabular}{|c|c|c|}
\hline \multicolumn{3}{|c|}{$\begin{array}{l}\text { School C } \\
\text { State-maintained Catholic Girls' School in West London (all students female) } \\
11 \text { May } 2018 \\
\text { Interviewer: Martin Spafford }\end{array}$} \\
\hline Year group & Student or teacher identifier & Heritage or heritages of student or teacher \\
\hline Y11 & A-F11C & Jamaica \\
\hline Y11 & B-F11C & Ireland \\
\hline Y11 & C-F11C & India \\
\hline Y11 & D-F11C & Kenya/Somalia \\
\hline Y11 & E-F11C & Zimbabwe/Nigeria \\
\hline Y11 & F-F11C & Ghana-1 \\
\hline Y11 & G-F11C & Ghana-2 \\
\hline Y11 & H-F11C & Ghana-3 \\
\hline Y11 & $\mathrm{I}-\mathrm{F} 11 \mathrm{C}$ & Ireland/Grenada \\
\hline $\mathrm{T} 4$ & C-FT1 & $\begin{array}{l}\text { Female w/White Irish heritage } \\
\text { Present at interview with students }\end{array}$ \\
\hline T5 & C-FT2 & $\begin{array}{l}\text { Female b/Black East African heritage } \\
\text { Present at interview with students }\end{array}$ \\
\hline
\end{tabular}


Table 4: School D Y9 students and their teacher

\begin{tabular}{|c|c|c|}
\hline \multicolumn{3}{|c|}{$\begin{array}{l}\text { School D } \\
\text { State-maintained Mixed Comprehensive School in North London } \\
16 \text { May } 2018 \\
\text { Interviewer: Martin Spafford }\end{array}$} \\
\hline Year group & Student or teacher identifier & Heritage or heritages of student or teacher \\
\hline Y9 & A-F9D (female) & São Tomé \& Principé/ Portugal \\
\hline Y9 & B-F9D (female) & Somalia/ Yemen/ Saudi Arabia \\
\hline Y9 & C-F9D (female) & Algeria \\
\hline Y9 & D-M9D (male) & Bangladesh \\
\hline Y9 & E-M9D (male) & Somalia/ Yemen \\
\hline Y9 & F-F9D (female) & Montserrat/ USA \\
\hline T6 & D-MT1 & $\begin{array}{l}\text { Lead Practitioner (History) male teacher }-\mathrm{w} / \text { White } \\
\text { British (Jewish heritage) } \\
\text { Present at interview with students }\end{array}$ \\
\hline
\end{tabular}

Table 5: School E Y9 students and their teacher

\begin{tabular}{|c|c|c|}
\hline \multicolumn{3}{|c|}{$\begin{array}{l}\text { School E } \\
\text { State-maintained Mixed Comprehensive School in East London } \\
22 \text { May } 2018 \\
\text { Interviewer: Martin Spafford }\end{array}$} \\
\hline Year group & Student or teacher identifier & Heritage or heritages of student or teacher \\
\hline Y9 & A-F9E (female) & India, Jamaica, Dominica, France \\
\hline Y9 & B-F9E (female) & Ghana \\
\hline Y9 & C-F9E (female) & Jamaica, Cuba \\
\hline Y9 & D-M9E (male) & Vietnam, Cumbria \\
\hline $\mathrm{T} 7$ & E-FT1 & $\begin{array}{l}\text { Female Head of History (b/Black British - West African } \\
\text { [Ghana]) } \\
\text { Present at interview with students }\end{array}$ \\
\hline
\end{tabular}

Table 6: Explanation of school year nomenclature

\begin{tabular}{|l|l|}
\hline School year & Stage related to National Curriculum or examination course \\
\hline Y9 & $\begin{array}{l}\text { The third year of secondary education (student ages 13-14). It is officially anyway, the } \\
\text { last year of Key Stage 3 (KS3), the stage before the GCSE exam course. }\end{array}$ \\
\hline Y11 & $\begin{array}{l}\text { The fifth year of secondary education (student ages 15-16). Y11 is the year when GCSE } \\
\text { examinations are taken. }\end{array}$ \\
\hline Y12 & $\begin{array}{l}\text { The sixth year of secondary education (student ages 16-17). The first of the two A-Level } \\
\text { years }\end{array}$ \\
\hline Y13 & $\begin{array}{l}\text { The seventh and usually last year of secondary education (student ages 17-18). The } \\
\text { second of the two A-Level years. The results of A-Level (Advanced Level) exams are } \\
\text { taken into account when students apply for university. }\end{array}$ \\
\hline
\end{tabular}


Table 7: Student and teacher interview questions organised under themes

\begin{tabular}{|c|c|c|}
\hline \multirow{2}{*}{$\begin{array}{l}\text { Question } \\
\text { number }\end{array}$} & \multicolumn{2}{|c|}{ THEME 1: Double-consciousness: relating their lives to the world } \\
\hline & Student questions & Teacher questions \\
\hline \multirow[t]{3}{*}{1} & $\begin{array}{l}\text { How do you see the relationship between your own } \\
\text { identity and history (e.g. the history of members of } \\
\text { your family) and being British in your own way? }\end{array}$ & $\begin{array}{l}\text { Drawing on your own experience of teaching } \\
\text { in a BAME community can you see any } \\
\text { effective practical solutions to address the } \\
\text { need for diversity and inclusion, perhaps } \\
\text { also bearing in mind question } 4 \text { below? }\end{array}$ \\
\hline & & $\begin{array}{l}\text { Would some, many or most BAME students } \\
\text { believe that they have more than one } \\
\text { identity? }\end{array}$ \\
\hline & \multicolumn{2}{|c|}{ THEME 2: Curriculum and pedagogy: relating their lives to the curriculum } \\
\hline \multirow[t]{2}{*}{2.} & $\begin{array}{l}\text { How far do you feel that this is reflected in what you } \\
\text { are taught? }\end{array}$ & $\begin{array}{l}\text { In what ways might it be possible to design } \\
\text { history education programmes that address } \\
\text { not only the necessity to 'cover' the } \\
\text { syllabuses or curricula, but which allow for } \\
\text { more personalisation to include diversity, } \\
\text { related specifically to the make-up of the } \\
\text { students in the classes? }\end{array}$ \\
\hline & & $\begin{array}{l}\text { Are there any landmark events that relate to } \\
\text { the questions above about inclusive } \\
\text { narratives and diversity that are } \\
\text { transnational, supranational or } \\
\text { international that many or all BAME } \\
\text { students might be able to identity with? }\end{array}$ \\
\hline \multirow[t]{3}{*}{3} & $\begin{array}{l}\text { What examples can you remember of teaching about } \\
\text { the history of empire, colonialism and decolonisation, } \\
\text { etc? }\end{array}$ & $\begin{array}{l}\text { Can you please give some examples of what } \\
\text { historical themes and events around empire, } \\
\text { decolonisation, and the Commonwealth are } \\
\text { taught? }\end{array}$ \\
\hline & & $\begin{array}{l}\text { What particular pedagogic and professional } \\
\text { knowledge do you draw upon in teaching } \\
\text { themes related to empire and post- } \\
\text { colonialism? (This relates to how historical } \\
\text { themes and events around empire, } \\
\text { decolonisation, and the Commonwealth are } \\
\text { taught.) }\end{array}$ \\
\hline & \multicolumn{2}{|c|}{$\begin{array}{l}\text { THEME 3: Understanding power relations: relating their understanding of power relations to } \\
\text { curriculum and society }\end{array}$} \\
\hline 4 & $\begin{array}{l}\text { How did you feel about your lessons about empire } \\
\text { and the way they were taught? }\end{array}$ & $\begin{array}{l}\text { Are you aware of any links between history } \\
\text { education debates in the BAME postcolonial } \\
\text { contexts with which you are familiar and } \\
\text { wider global discourses about history } \\
\text { education? }\end{array}$ \\
\hline \multirow[t]{2}{*}{5} & Would you like to see any changes in what is taught? & $\begin{array}{l}\text { Should professional or other bodies (e.g. the } \\
\text { Historical Association, SHP, even the Royal } \\
\text { Historical Society, or the Commonwealth) } \\
\text { [this was extended to include the } \\
\text { government] be doing more to ensure more } \\
\text { diversity in history education? }\end{array}$ \\
\hline & \multicolumn{2}{|c|}{ THEME 4: Citizenship, social justice and curriculum change } \\
\hline 6 & If yes, what changes? & If they should be, then how or in what way? \\
\hline & & $\begin{array}{l}\text { Have you experienced the need to give } \\
\text { citizenship education for BAME students a } \\
\text { historical dimension that they can identify } \\
\text { with? }\end{array}$ \\
\hline
\end{tabular}

Table 8: Overarching methodology: Habitus-Field relational phenomenology as a way of exploring 'decolonising the curriculum' 


\begin{tabular}{|c|c|c|}
\hline Habitus & $\begin{array}{l}\text { Element of relational } \\
\text { phenomenology }\end{array}$ & Field \\
\hline \multirow{2}{*}{$\begin{array}{l}\text { Habitus } 1 \\
\text { Human consciousness } \\
\text { (including double or multiple } \\
\text { consciousness[es]) and } \\
\text { locational awareness gained } \\
\text { through personal and family } \\
\text { experience (students) or } \\
\text { through personal and } \\
\text { professional experience } \\
\text { (teachers) (life-world } \\
\text { experience) }\end{array}$} & $\begin{array}{l}\text { Relating their lives to the } \\
\text { world and others } \\
\text { [Theme 1] }\end{array}$ & $\begin{array}{l}\text { Field 1 } \\
\text { The life-world experiences of } \\
\text { others in the immediate, wider } \\
\text { and global 'demographic' in time } \\
\text { and space }\end{array}$ \\
\hline & $\begin{array}{l}\text { Relating their lives to the } \\
\text { curriculum } \\
\text { [Theme 2] }\end{array}$ & $\begin{array}{l}\text { Field } 2 \\
\text { What is taught and learnt about } \\
\text { empire, colonisation and } \\
\text { decolonisation in school history }\end{array}$ \\
\hline $\begin{array}{l}\text { Habitus } 2 \\
\text { Personal and professional } \\
\text { experiences and } \\
\text { understandings of power } \\
\text { relationships in everyday life, } \\
\text { in the family, in school, as } \\
\text { encountered in the history } \\
\text { curriculum, and in the wider } \\
\text { society (including everyday } \\
\text { understandings of identity, } \\
\text { plurality, diversity and } \\
\text { inclusion) }\end{array}$ & $\begin{array}{l}\text { Relating their } \\
\text { understanding of power } \\
\text { relations to curriculum and } \\
\text { society } \\
\text { [Theme 3] }\end{array}$ & $\begin{array}{l}\text { Field } 3 \\
\text { Fields in which power relations } \\
\text { are at play: in everyday life, in the } \\
\text { family, in school, as encountered } \\
\text { in the history curriculum, and in } \\
\text { the wider society }\end{array}$ \\
\hline $\begin{array}{l}\text { Habitus } 3 \\
\text { A personal and professional } \\
\text { sense of justice and } \\
\text { commitment to change related } \\
\text { to inequalities in the wider } \\
\text { society }\end{array}$ & $\begin{array}{l}\text { Relating the students' and } \\
\text { teachers' sense of social } \\
\text { justice and commitment to } \\
\text { change to power relations in } \\
\text { curriculum and society } \\
\text { [Theme 4] }\end{array}$ & \\
\hline
\end{tabular}


Table 9: Overall research question, theme-related sub-questions and focus of work based on relational phenomenology

\begin{tabular}{|l|l|}
\hline Overall research question & $\begin{array}{l}\text { How are the habitus-field relationships in Table 8 as related phenomena } \\
\text { explicated both holistically and dialectically in the context of these four sets of } \\
\text { theme-related questions as a way of exploring 'decolonising the curriculum'? }\end{array}$ \\
\hline Themes, theme-related sub-questions and related phenomena \\
\hline Theme 1 & $\begin{array}{l}\text { 1. Double-consciousness: relating their lives (habitus 1) to the world } \\
\text { (field 1) } \\
\text { How are the phenomena of and relationships between 'metropole and colony' } \\
\text { (or core and periphery) explored in the conversations in accounts of the life- } \\
\text { world experiences of the students and their teachers? }\end{array}$ \\
\hline Theme 2 & $\begin{array}{l}\text { 2. Curriculum and pedagogy: relating their lives (habitus 1) to the } \\
\text { curriculum (field 2) } \\
\text { How are the phenomena/relationships (in Theme 1) reflected or developed in } \\
\text { the conversations as factors in decolonising the curriculum and the associated } \\
\text { pedagogy? } \\
\text { (i) curriculum: how are the existing frameworks within which the colonisation, } \\
\text { imperial and decolonisation elements appear in the history curriculum } \\
\text { experienced by these students and enacted by their teachers? } \\
\text { (ii) pedagogy: what pedagogical methods are discussed and which are seen } \\
\text { being most effective? }\end{array}$ \\
\hline Theme 3 & $\begin{array}{l}\text { 3. Understanding power relations: relating their understanding of power } \\
\text { relations (habitus 2) to curriculum and society (field 3) } \\
\text { (i) To what extent is the personal also political in the perceptions of these } \\
\text { students and their teachers? (related to everyday understandings of the power } \\
\text { relations behind the workings of identity, plurality, diversity and inclusion) } \\
\text { (ii) How do teachers and students work together to achieve agency and see } \\
\text { themselves in the narrative? }\end{array}$ \\
$\begin{array}{l}\text { 4. Citizenship, social justice and curriculum change: relating the students' } \\
\text { and teachers' sense of justice and commitment to change (habitus 3) to } \\
\text { curriculum and society (field 3) } \\
\text { How do citizenship dimensions related to reflections about justice, inequality } \\
\text { and curriculum change emerge as observations, concerns or recommendations } \\
\text { from the conversations (not just for BAME students but for all English or even } \\
\text { all UK students)? }\end{array}$ \\
\hline Theme 4
\end{tabular}




\section{Endnotes}

${ }^{1}$ Stephen Lawrence, aged 18, was murdered in a racially motivated attack in Eltham, SE London on 22 April 1993. His parents settled in Britain from Jamaica in the 1960s. Kelso Cochrane, aged 32, of Antiguan heritage, was murdered, also in stabbing attack, on 17 May 1959.

${ }^{2}$ The original ship, the SS Empire Windrush brought 500-plus postwar, much-needed migrant workers from the Caribbean to London in 1948. The 'Windrush Generation' is a name applied to these and subsequent migrants, but more recently, particularly in 2018, the scandalous treatment of later migrants from the Caribbean has been highlighted by The Guardian, and in particular in Amelia Gentleman's work (Gentleman, 2019).

${ }^{3}$ Commonwealth Heads of Government Meetings (CHOGMs) are customarily held in a Commonwealth capital city every two years, although because of Covid-19 restrictions the next one after London 2018 will be held in June 2021. They are consultative and policy-making gatherings to which representatives of all fifty-four Commonwealth jurisdictions are invited.

${ }^{4}$ Martin Spafford taught history for many years in secondary schools in East and West London and has previously taught in eSwatini, Rotherham and Egypt. He is an Honorary Fellow of both the Historical Association and the Schools History Project. He was a co-author of textbooks for GCSE courses on migration history.

\section{Acknowledgements}

I would like to thank Martin Spafford for organising, undertaking and transcribing these interview-conversations. The involvement of the 7 teachers in the 5 London schools and the 33 students who took part is acknowledged with considerable gratitude.

\section{Metadata Note}

A metadata file containing the transcripts of London student and teacher interview-conversations from April-May 2018 is available from the "Metadata" link available on the article's landing page: https://www.hej-hermes.net/8-209

\section{About the Author}

Robert Guyver was a primary teacher for 21 years, an advisory teacher, and a lecturer in initial teacher education in Plymouth. To contact the author please use the email address below.

\section{Email: guyverrobert@gmail.com}

